\title{
Influence of Novel Endophytic Fungus Piriformospora indica on Growth and Yield of Finger Millet (Eleusine coracana G.) in Combination with N Fixer and P Solubilizer
}

\author{
G.P. Arunkumar* and M.K. Shivaprakash \\ Department of Agricultural Microbiology, University of Agricultural Sciences, \\ GKVK, Bangalore, Karnataka, India \\ *Corresponding author
}

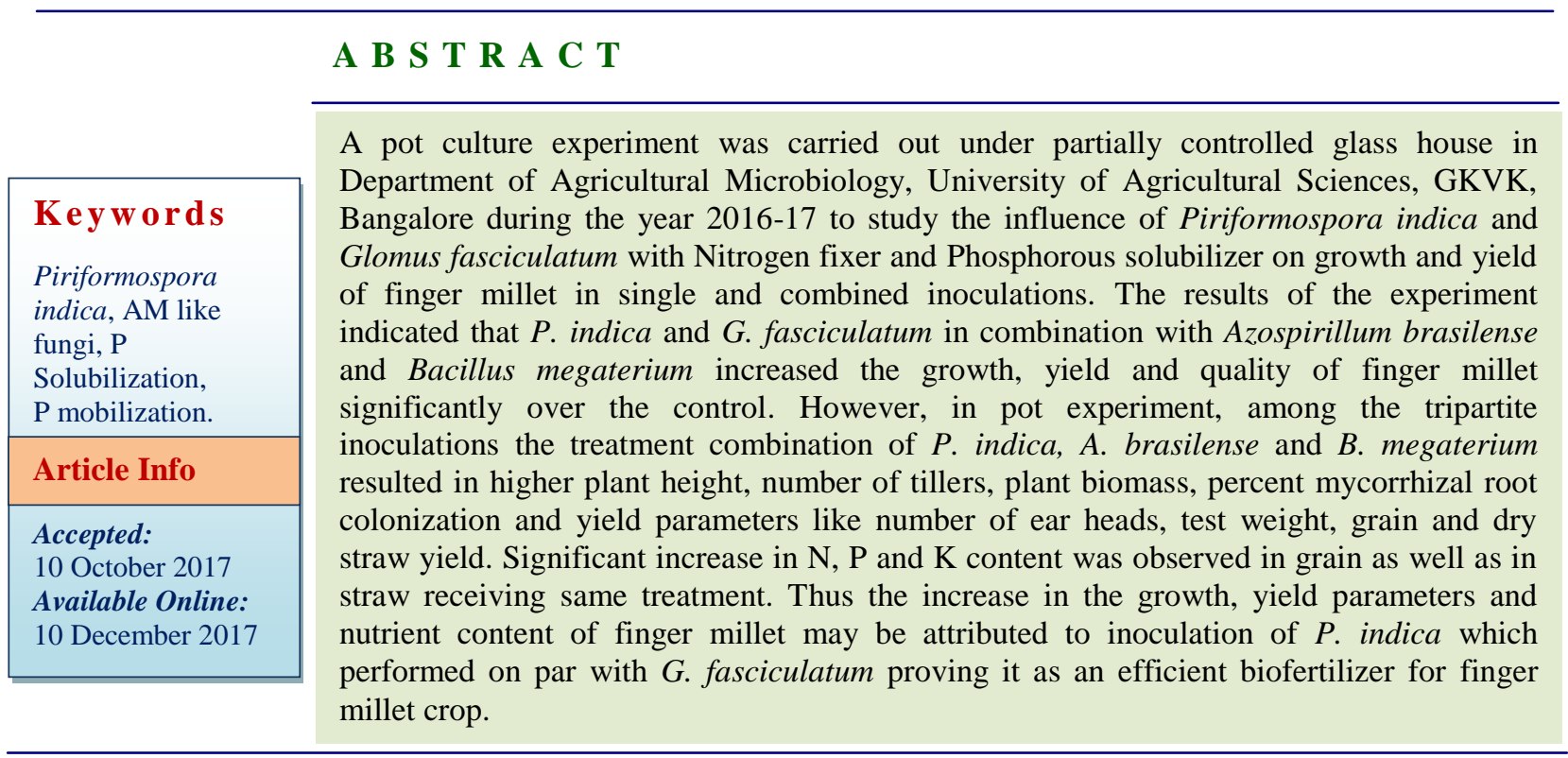

\section{Introduction}

Eleusine coracana $\mathrm{G}$. is commonly called as finger millet or African millet since originated from Africa, locally called as Ragi in Karnataka (a major producing state in India). It is the third most important millet in India, next to sorghum and pearl millet, covering an area of about $1.04 \mathrm{M}$ ha, with an annual production of $1.85 \mathrm{MT}$ (as per first estimate for the year 2016-17). The most striking feature which made finger millet an important dry land crop is its ability to withstand adverse weather conditions like drought as well as resilient ability. It is nutritionally richas it contains high levels of calcium, iron and manganese compared to polished rice and maize.

Piriformospora indica is an endophytic fungus having wide range of hosts which mimics the AM fungi in function, like phosphorus mobilization, by and large it acts as fungal plant root thus known to be the AM 
like fungus. This can be cultured axenically, which gives propound advantage over the conventional AM fungi, which are obligate in nature and pose extreme difficulty in mass multiplication and maintenance. There have been many experimental trials for exploiting potential of this fungus in many crops and found to be significant in the results but this fungus was not put in trail with the finger millet yet. The interaction of the fungus with the $\mathrm{N}$ fixers, $\mathrm{P}$ - mobilizers and $\mathrm{P}$ - solubilizers were less documented (Varma et al., 2012)

The availability of phosphorous could be a limiting factor for plant growth as well as bacterial survival. The demand for the phosphorous could be met with the AM fungi which mobilize the phosphorous from non rhizospheric soil. Plant growth promotion and enhanced nutrient uptake with interaction of AM fungi, $\mathrm{N}$ fixers and PSB was well documented by Patil et al., (2013) in Eleusine coracana $\mathrm{G}$. In the current study, influence of $P$. indica with $\mathrm{N}$ fixer and $\mathrm{P}$ solubilizer was compared with interactive effect of Glomus facsiculatum with $\mathrm{N}$ fixer and $\mathrm{P}$ solubilizer on growth and yield of Eleusine coracana $\mathrm{G}$.

\section{Materials and Methods}

The pot culture experiment was conducted under partially controlled glass house in Department of Agricultural Microbiology, University of Agricultural Sciences, Gandhi Krishi Vigyana Kendra (GKVK) campus, Bangalore, during the year 2016-17 using finger millet (Eleusine coracana G.) variety KMR-204 as test crop.

The experiment comprised of 8 treatments replicated 3 times and was laid out in Completely Randomized Design (CRD). As the source of organic matter the soil was supplemented with vermicompost in the ratio of 5:2 (soil: vermicompost). Microbial inoculants used in this study were
Piriformospora indica, Glomus fasciculatum, Azospirillum brasilense and Bacillus megaterium. Piriformospora indica culture was procured from the Dr. Ajit Varma, Amity University (UP). Mass multiplied in Hill and Kafer broth and prepared talk based formulation inoculum (5 per cent w/w). Soil based inoculum in pot cultures of Glomus fasciculatum maintained since 4 months with Sorghum bicolor as the host using sterilized soil under glasshouse condition was used for the experiment. The infected root fragments of Sorghum bicolor and rhizosphere soil with spore count of 60 spores/g of soil constituted G. fasciculatum inoculum. Both inoculums were mixed with a portion of soil vermicompost mixture $20 \mathrm{~g}$ inoculum per pot was layered following the "sandwich model" (Varma and Scheupp 1995).

Remaining microbial cultures were collected from the culture collection unit of Department of Agricultural Microbiology, UAS, GKVK, Bangalore. Mass multiplied in respective specific media for Azospirillum brasilense Dobereiner's N-free malate broth with BTB (Bromothymolblue $5 \%$ alcoholic solution) $\mathrm{pH}$ indicator $\left(2 \times 10^{6} \mathrm{CFU}\right.$ per $\left.\mathrm{ml}\right)$ and for Bacillus megaterium Pikovskays media $\left(8 \times 10^{6} \mathrm{CFU}\right.$ per $\left.\mathrm{ml}\right)$ and applied as seed treatment

Growth parameters were recorded at 30, 60 DAT and at harvest, while yield parameters were recorded after harvest. Plant samples were analyzed for total N, P and Kusing standard methods of analysis Jackson (1973).

\section{Results and Discussion}

The significant differences were noted in the plant height. At 30, 60 DAT and at harvest plant height found to be highest in the treatment $\left(\mathrm{T}_{8}\right)$ with combination of all test organism $(73.33 \mathrm{~cm}, 86.17 \mathrm{~cm}$ and 105.83 $\mathrm{cm})$, which differed significantly from 
treatment $\left(\mathrm{T}_{7}\right)$ receiving $P$. indica in combination with $A$. barasilense and $B$. megaterium $(72.33 \mathrm{~cm}, 85.50 \mathrm{~cm}$ and 104.43 $\mathrm{cm})$ which in turn performed on par with treatment $\left(\mathrm{T}_{6}\right)$ comprising of $G$. Fasciculatum inoculation in combination with $A$. barasilense and $B$. megaterium $(71.67 \mathrm{~cm}$, $85.08 \mathrm{~cm}$ and $104.33 \mathrm{~cm}$ ) the lowest plant height was observed in control $(52.33 \mathrm{~cm}$, $73.50 \mathrm{~cm}$ and 85.75 ) respectively (Table 1 ).

The increased plant height of the crop may be due to the increased nutrient availability to the plants by the influence of imposed treatments with organisms the results of this study were in congruence with the study of Krishnaveni et al., (2015). She reported, plants that were colonized by the fungus showed excellent growth in height when compared to that of control plants and their difference in shoot and root height in pot studies had shown that the fungus could effectively induce increase in growth of colonized plants.

Maximum number of tillers per plant, at 30 DAT was in the treatment $\left(\mathrm{T}_{8}\right)$ with all test organisms (3.00) which was on par with $\left(\mathrm{T}_{7}\right)$ $P$. indica in combination with $A$. barasilense and $B$. megaterium (2.33) and the treatment $\left(\mathrm{T}_{6}\right)$ receiving $G$. fasciculatum in combination with $A$. barasilense and $B$. megaterium (2.67) the significantly lowest number of tillers per plant was recorded in the control (1.33). The same trend was followed at 60 and at harvest stage. Less number of tillers was recorded in uninoculated control. The increased number of tillers may be due the increased nutrition by the action of the imposed treatments with microbial inoculants. Similar results were obtained by Das et al., (2013) by inoculation of rice with either $P$. indica or $G$. fasciculatum alone or combination of both showed significant improvement in plant growth parameters (plant height, number of leaves and tillers) compared to un-inoculated. Significant difference was recorded in the plant biomass among all the treatments depicted in the figure 1. Highest biomass was recorded in the treatment $\left(\mathrm{T}_{8}\right) 48.40 \mathrm{~g} \mathrm{plant}^{-1}$ significantly differ from $\left(\mathrm{T}_{7}\right) 47.28 \mathrm{~g} \mathrm{plant}^{-1}$, control being recorded lowest $37.00 \mathrm{~g} \mathrm{plant}^{-1}$ differ significantly from the rest of other treatments. Treatments receiving inoculants were significantly different from the uninoculated control. The increase in plant biomass may be due to increased mobilization of nutrient to the plants by the inoculated microorganisms which might have led to the accumulation of photosynthates in plant system. Similar results were recorded by Varma et al., (1999) who reported an increase in root and shoot biomass for $P$. indica treatment in maize over the control

Significant increase in number of earheads per plant, grain yield and straw yield were noticed when inoculated either with $P$. indica, $G$. fasciculatumor both along with $A$. brasilence and B. megaterium.

However plants treated with combination of all the test organisms $\left(\mathrm{T}_{8}\right)$ recorded significantly higher yield from that of $P$. indica or $G$. fasciculatum along with $A$. brasilence and B. megaterium. Although there is no significant difference among plants receiving these treatments but plants inoculated with $P$. indica along with $A$. brasilence and $B$. megaterium $\left(\mathrm{T}_{7}\right)$ recorded slightly higher yields than that of plants inoculated with $G$. fasciculatum along with $A$. brasilence and $B$. megaterium $\left(\mathrm{T}_{6}\right)$.

Earhead parameters (Table 2) clearly shows significant difference in number of earheads, number of fingers and their length among the treatments however $\mathrm{T}_{8}$ recorded highest (5.67, 7.50 , and $8.17 \mathrm{~cm}$ respectively) followed by $\mathrm{T}_{7}(5.33,7.17$ and $7.90 \mathrm{~cm}$ respectively) least being recorded in control (3.00, 4.42, $5.19 \mathrm{~cm})$. 
Table.1 Influence of $P$. indica, $G$. fasciculatum, A. brasilense and B. megaterium on plant height and number of tillers at different growth stages of Finger millet

\begin{tabular}{|c|c|c|c|c|c|c|c|}
\hline & \multirow[b]{2}{*}{ Treatment details } & \multicolumn{3}{|c|}{ Plant height (cm) } & \multicolumn{3}{|c|}{ Number of tillers } \\
\hline & & 30 DAT & 60 DAT & $\begin{array}{c}\text { At } \\
\text { harvest }\end{array}$ & $\begin{array}{c}30 \\
\text { DAT }\end{array}$ & $\begin{array}{c}\text { 60 } \\
\text { DAT }\end{array}$ & $\begin{array}{c}\text { At } \\
\text { harvest }\end{array}$ \\
\hline $\mathrm{T}_{1}:$ & Control & $52.33^{\mathrm{f}}$ & $73.50^{f}$ & $85.75^{\mathrm{e}}$ & $1.33^{\mathrm{d}}$ & $3.33^{d}$ & $4.17^{\mathrm{e}}$ \\
\hline $\mathrm{T}_{2}:$ & $\begin{array}{l}\text { Azospirillum } \\
\text { brasilense }\end{array}$ & $66.33^{\mathrm{d}}$ & $81.50^{\mathrm{d}}$ & $102.67^{\mathrm{c}}$ & $1.67^{\mathrm{cd}}$ & $4.50^{\mathrm{bc}}$ & $4.33^{\mathrm{de}}$ \\
\hline $\mathrm{T}_{3}:$ & Bacillus megaterium & $64.33^{\mathrm{e}}$ & $79.50^{\mathrm{e}}$ & $99.17^{\mathrm{d}}$ & $1.67^{\mathrm{cd}}$ & $4.17^{\mathrm{c}}$ & $4.33^{\text {cde }}$ \\
\hline $\mathrm{T}_{4}:$ & $\begin{array}{l}\text { Glomous } \\
\text { fasciculatum }\end{array}$ & $66.33^{\mathrm{d}}$ & $81.25^{\mathrm{d}}$ & $103.00^{c}$ & $1.67^{\mathrm{cd}}$ & $4.67^{\mathrm{abc}}$ & $4.67^{\mathrm{bcd}}$ \\
\hline $\mathrm{T}_{5}:$ & $\begin{array}{l}\text { Piriformospora } \\
\text { indica }\end{array}$ & $67.67^{\mathrm{c}}$ & $82.17^{\mathrm{c}}$ & $103.17^{\mathrm{c}}$ & $2.00^{\mathrm{bcd}}$ & $4.67^{\mathrm{abc}}$ & $4.67^{\mathrm{abc}}$ \\
\hline $\mathrm{T}_{6}:$ & A. $b+B . m+G . f$ & $71.67^{\mathrm{b}}$ & $85.08^{\mathrm{b}}$ & $104.33^{b}$ & $2.67^{\mathrm{ab}}$ & $4.83^{\mathrm{abc}}$ & $4.83^{\mathrm{ab}}$ \\
\hline $\mathrm{T}_{7}:$ & $A . b+B . m+P . i$ & $72.33^{\mathrm{ab}}$ & $85.50^{\mathrm{b}}$ & $104.43^{b}$ & $2.33^{\mathrm{abc}}$ & $5.17^{\mathrm{ab}}$ & $4.83^{\mathrm{ab}}$ \\
\hline $\begin{array}{l}\mathrm{T}_{8}: \\
G . f\end{array}$ & A. $b+B . m+P . i+$ & $73.33^{\mathrm{a}}$ & $86.17^{\mathrm{a}}$ & $105.83^{\mathrm{a}}$ & $3.00^{\mathrm{a}}$ & $5.33^{\mathrm{a}}$ & $4.83^{\mathrm{a}}$ \\
\hline & CD@1\% & 1.17 & 0.49 & 0.68 & 0.87 & 0.71 & 0.84 \\
\hline
\end{tabular}

Note: Means with same superscript do not differ significantly at $p=0.01$ level of Duncan's multiple range

Table.2 Influence of $P$. indica and G. fasciculatum with $\mathrm{N}$ fixer and $\mathrm{P}$ solubilizers on yield parameters of Eleusine coracana $\mathrm{G}$.

\begin{tabular}{|c|c|c|c|c|c|c|c|}
\hline & \multirow[b]{2}{*}{ Treatment details } & \multicolumn{6}{|c|}{ Yield parameters } \\
\hline & & $\begin{array}{c}\text { No. of } \\
\text { ear } \\
\text { heads } \\
\text { plant }^{-1}\end{array}$ & $\begin{array}{c}\text { Number } \\
\text { of } \\
\text { fingers }\end{array}$ & $\begin{array}{l}\text { Length } \\
\text { of } \\
\text { fingers } \\
(\mathrm{cm}) \\
\end{array}$ & $\begin{array}{c}\text { Test } \\
\text { weight } \\
\text { of } 1000 \\
\text { seed }(\mathrm{g})\end{array}$ & $\begin{array}{l}\text { Grain } \\
\text { Yield } \\
\text { g } \\
\text { plant }^{-1}\end{array}$ & $\begin{array}{c}\text { Straw } \\
\text { yield } \\
\text { g plant }\end{array}$ \\
\hline $\mathrm{T}_{1}:$ & Control & $3.00^{\mathrm{g}}$ & $4.42^{\mathrm{e}}$ & $5.19^{f}$ & $52.33^{\mathrm{f}}$ & $73.50^{f}$ & $85.75^{\mathrm{e}}$ \\
\hline $\mathrm{T}_{2}$ : & $\begin{array}{l}\text { Azospirillum } \\
\text { brasilense }\end{array}$ & $3.33^{\mathrm{fg}}$ & $5.58^{\mathrm{c}}$ & $6.54^{\mathrm{c}}$ & $66.33^{d}$ & $81.50^{\mathrm{d}}$ & $102.67^{c}$ \\
\hline $\mathrm{T}_{3}:$ & Bacillus megaterium & $3.67^{\mathrm{ef}}$ & $5.00^{\mathrm{d}}$ & $5.63^{\mathrm{e}}$ & $64.33^{\mathrm{e}}$ & $79.50^{\mathrm{e}}$ & $99.17^{\mathrm{d}}$ \\
\hline $\mathrm{T}_{4}:$ & $\begin{array}{l}\text { Glomous } \\
\text { fasciculatum }\end{array}$ & $4.17^{\mathrm{de}}$ & $5.33^{\mathrm{cd}}$ & $6.11^{d}$ & $66.33^{d}$ & $81.25^{\mathrm{d}}$ & $103.00^{c}$ \\
\hline $\mathrm{T}_{5}:$ & $\begin{array}{l}\text { Piriformospora } \\
\text { indica }\end{array}$ & $4.50^{\mathrm{cd}}$ & $5.83^{c}$ & $6.19^{\mathrm{cd}}$ & $67.67^{\mathrm{c}}$ & $82.17^{\mathrm{c}}$ & $103.17^{\mathrm{c}}$ \\
\hline $\mathrm{T}_{6}:$ & A. $b+B \cdot m+G \cdot f$ & $5.00^{\mathrm{bc}}$ & $6.67^{\mathrm{b}}$ & $7.42^{\mathrm{b}}$ & $71.67^{\mathrm{b}}$ & $85.08^{\mathrm{b}}$ & $104.33^{b}$ \\
\hline $\mathrm{T}_{7}:$ & $A . b+B . m+P . i$ & $5.33^{\mathrm{ab}}$ & $7.17^{\mathrm{ab}}$ & $7.90^{\mathrm{a}}$ & $72.33^{\mathrm{ab}}$ & $85.50^{\mathrm{b}}$ & $104.43^{b}$ \\
\hline \multirow[t]{2}{*}{$\begin{array}{l}\mathrm{T}_{8}: \\
G . f\end{array}$} & A. $b+B . m+P . i+$ & $5.67^{\mathrm{a}}$ & $7.50^{\mathrm{a}}$ & $8.17^{\mathrm{a}}$ & $73.33^{\mathrm{a}}$ & $86.17^{\mathrm{a}}$ & $105.83^{\mathrm{a}}$ \\
\hline & CD@1\% & 0.66 & 0.51 & 0.37 & 1.17 & 0.49 & 0.68 \\
\hline
\end{tabular}

Note: Means with same superscript do not differ significantly at $p=0.01$ level of Duncan's multiple range 
Fig.1 Effect of $P$. indica, G. fasciculatum, A. brasilense and B. megaterium in combinations on plant biomass of Ragi

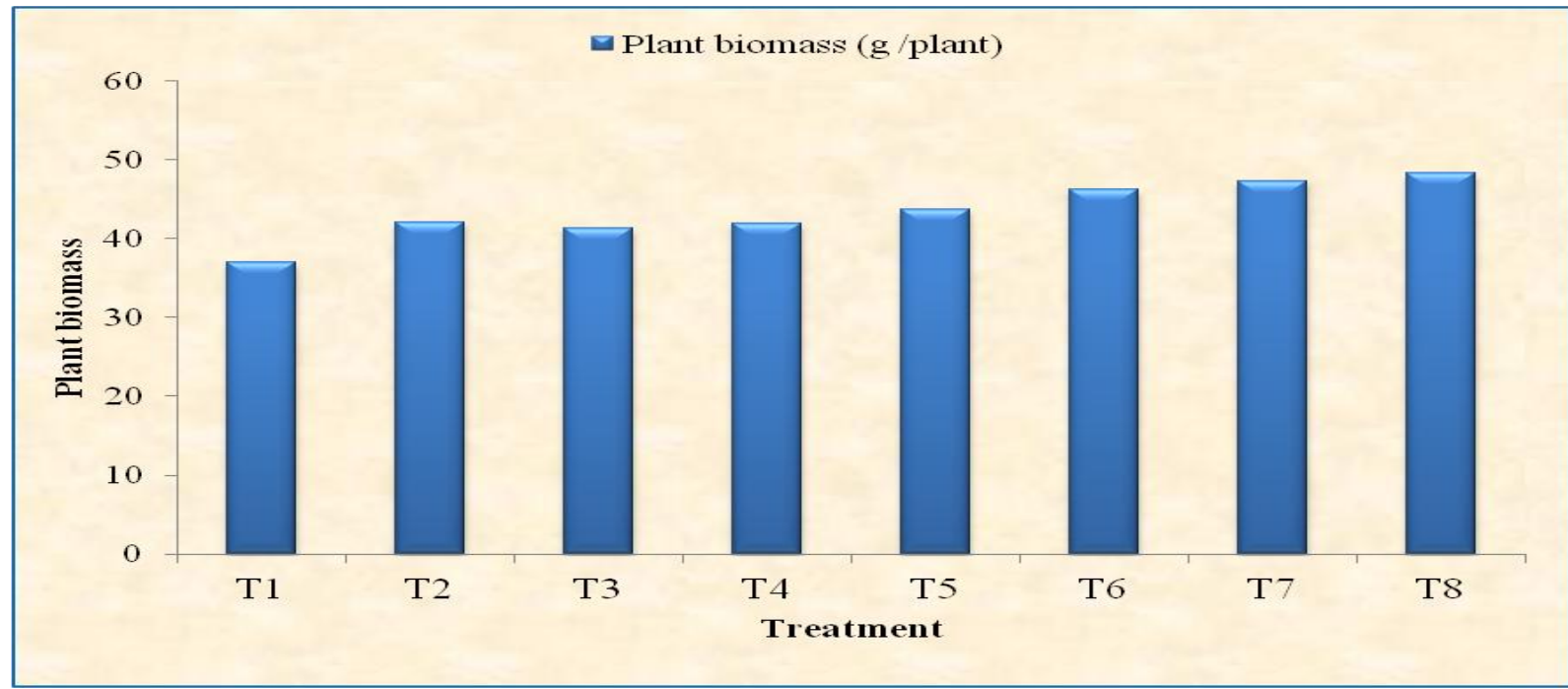

Legend

$\mathbf{T}_{\mathbf{1}}$ Control $\mathbf{T}_{\mathbf{2}}$ Azospirillum brasilense $\mathbf{T}_{\mathbf{3}}$ Bacillus megaterium $\mathbf{T}_{\mathbf{4}}$ Glomous fasciculatum

$\mathbf{T}_{5}$ Piriformosporaindica $\mathbf{T}_{\mathbf{6}}$ A. brasilense $+B$. megaterium $+P$. indica

$\mathbf{T}_{7}$ A. brasilense $+B$. megaterium $+G$. fasciculatum

$\mathbf{T}_{\mathbf{8}}$ A. brasilense + B. megaterium + G. fasciculatum $+P$. indica

The yield parameters of finger millet like test weight, grain yield and straw yield as influenced by the inoculation of $P$. indica, $G$. fasciculatum, Azospirillum brasilense and Bacillus megaterium individually and in combination are furnished in the Table 2. There was significant difference among the treatments in yield parameters as influenced by the inoculation of the microbial inoculants Highest test weight $(73.33 \mathrm{~g} / 1000$ seeds), grain yield $\left(86.17 \mathrm{~g}\right.$ plant $\left.^{-1}\right)$ and straw yield $\left(105.83 \mathrm{~g} \mathrm{plant}^{-1}\right)$ were recorded in $\mathrm{T}_{8}$ with tetrapartite inoculation followed by $\mathrm{T}_{7}$ and $\mathrm{T}_{6}$ which was significantly different from each other in case of grain and straw yield and were at on par with respect to test weight. The increase in the yield may be attributed to the increased plant biomass and the ear head parameters like number of ear heads, length of the fingers which followed the same trend. The results were in accordance with results of Das et al., (2013).Waller et al., (2005) used the cereal model plant barley (Hordeum vulgare $L$.) to test whether growth-promoting activity of the $P$. indica associates with agronomically desirable traits. During the first 4 weeks of barley development, shoot fresh weight of infested plants was up to 1.65 times higher compared with control plants. Two barley cultivars, including the elite cultivar Annabell, were tested. $P$. indica-infested Annabell showed an increase in grain yield of $11 \%$, mainly because of a higher number of ears per plant. In cultivar Ingrid, the grain yield increase was 5.5\%.

The total nitrogen content in the grain and straw respectively, found to be highest in the treatment $\mathrm{T}_{8}(1.52 \%, 0.62 \%)$ followed by $\mathrm{T}_{7}$ $(1.51 \%, 0.60 \%)$ least in control $(1.16 \%$, $0.38 \%$ ). The total phosphorus content in the grain and straw, found to be highest in the treatment $\mathrm{T}_{8}(0.35 \%, 0.20 \%)$ followed by $\mathrm{T}_{7}$ $(0.30 \%, 0.18 \%)$ least in control $(0.20 \%$, $0.15 \%)$. The total potassium content in the grain and straw, found to be highest in the treatment $\mathrm{T}_{8}(0.61 \%, 0.69 \%)$ followed by $\mathrm{T}_{7}$ $(0.58 \%, 0.66 \%)$ least in control $(0.36 \%$, 
0.53\%). Das et al., (2013) reported that the NPK content in shoot and root portions of rice plants were significantly higher when inoculated either with $P$. indica, $G$. fasciculatum or both compared to control plants. The increased nutrient uptake may be due to more nutrient translocation into the plants influenced by the microbial inoculants by modifying the root morphology as well as making nutrients easily available for the plants by Nitrogen fixing, Phosphorus solubilization and phosphorus mobilizing organisms.

The results of the present study undoubtedly show that the $P$. indica can perform as good as the conventional AM fungi in combination with Azospirillum brasilense and Bacillus megaterium. It can be used as alternative for the AM fungi being easily cultivable on axenically pose profound advantage in the mass multiplication and opportunity for utilization as effective biofertilizer in finger millet (Eleusine coracana $\mathrm{G}$.) cultivation.

\section{Acknowledgements}

I pledge my sincere thanks to Dr. AjitVarma, Prof. Amity University, UP, IND., for providing the Piriformosporaindica culture for the research needs.

\section{References}

Das, J., Ramesh, K., Maithri, U., Mutangana, D. and Suresh, C. K., 2013, Response of aerobic rice to Piriformospora indica. Ind. J. Expet. Biol., 52: 237-251.

Jackson, M. L., 1973, Soil Chemical Analysis. Prentice Hall Pvt. Ltd., New Delhi.

Krishnaveni, N., Geetha Ramani., Ranjitha, L. and Cibichakravarthy, B., 2015, Novel Cultivable Mycobiont Piriformospora indica as Plant Growth Promoting Endophyte. Int. Res. J. Biological Sci., 4(1): 11-15.

Patil, G. B., Lakshman, H. C., Romana, M. Mirdhe and Agadi, B. S. 2013, Effect of co-inoculation of AM fungi and two beneficial microorganisms of growth and nutrient uptake of Eleusine coracana Gaertn. (Finger millet). Asian J. Plant Sci. Res., 3(1): 26-30.

Varma, A. and Schuepp, H. 1995, Mycorrhization of micropropagated plantlets. In: Adholeya, A.; Singh, S., eds. Mycorrhizae: biofertilizers for the future. New Delhi: Tata Energy Research Institute, 322-327.

Varma, A., Bakshi, M., Lou, B., Hartmann, A. and Oelmuller, R., 2012, Piriformospora indica: A novel plant growth promoting mycorrhizal fungus. Agric. Res. 1(2): 117-131.

Varma, A., Verma, S., Sudha, Sahay, N., Butehorn, B. and Franken, P., 1999, Piriformospora indica, a cultivable plant-growth promoting root endophyte. Appl. Environ. Microbiol., 65(6): 27412744.

Waller, F., Achatz, B., Baltruschat, H., Fodor, J., Becker, K., Fischer, M., Heier, T., Huckelhoven, R., Neumann, C., Wettstein, D., Franken, P. and Kogel, K. H. 2005, The endophytic fungus Piriformospora indica reprograms barley to salt-stress tolerance, disease resistance, and higher yield, PNAS., 102(38): 13386-13391.

\section{How to cite this article:}

Arunkumar, G.P. and Shivaprakash, M.K. 2017. Influence of Novel Endophytic Fungus Piriformospora indica on Growth and Yield of Finger Millet (Eleusine coracana G.) in Combination with N Fixer and P Solubilizer. Int.J.Curr.Microbiol.App.Sci. 6(12): 1037-1042. doi: https://doi.org/10.20546/ijcmas.2017.612.116 